\title{
Solitary olfactory schwannoma without olfactory dysfunction: a new case report and literature review
}

\author{
Y. P. Li $\cdot$ S. Jiang $\cdot$ P. Z. Zhou $\cdot$ Y. B. Ni
}

Received: 20 January 2011 / Accepted: 26 March 2011/Published online: 12 April 2011

(c) The Author(s) 2011. This article is published with open access at Springerlink.com

\begin{abstract}
Schwannomas are rare and seldom extend into the anterior cranial fossa. Herein, we report a case of schwannoma arising from the olfactory groove in a 16-year-old girl who presented with generalized seizures without olfactory dysfunction or other neurologic deficits. Computerized tomography (CT) scan showed a large mass with abundant calcification located in the olfactory groove, which was confirmed as a schwannoma by histology and totally resected via basal subfrontal approach. The presentation, imaging findings and histogenesis of the tumor are discussed along with a review of the pertinent literature.
\end{abstract}

Keywords Olfactory groove $\cdot$ Subfrontal $\cdot$ Schwannoma Olfactory dysfunction

Y. P. Li · S. Jiang $(\varangle) \cdot$ P. Z. Zhou

Department of Neurosurgery, West China Hospital,

Sichuan University, Chengdu 610041, Sichuan,

People's Republic of China

e-mail: Leeurop@gmail.com

Y. P. Li

e-mail: andybile@gmail.com

P. Z. Zhou

e-mail: 150983737@qq.com

Y. B. Ni

Department of Pathology, West China Hospital,

Sichuan University, Chengdu 610041, Sichuan,

People's Republic of China

e-mail: 759230307@qq.com

\section{Introduction}

Intracranial schwannomas arise predominantly from the vestibular branch of the eighth cranial nerve and rarely from the olfactory groove. Olfactory groove schwannomas are rare and likely to be misdiagnosed as olfactory groove meningiomas, dural-based metastasis or neuroblastomas. Only about 30 cases of olfactory groove meningioma have been reported in the world literature, and most of these cases were associated with olfactory dysfunction, while only 13 cases were reported to have no olfactory dysfunction. In this article, we discuss a rare case of schwannoma arising from the olfactory groove in a 16-year-old girl who presented with generalized seizures without olfactory dysfunction.

\section{History}

A 16-year-old girl presented with episodes of generalized seizures in the past 15 years, and the attacks became more frequent in recent 2 years prior to admission in a local hospital, where a large subfrontal mass was noticed on computerized tomography (CT) scan (Fig. 1a). The patient was transferred to our hospital for further evaluation and treatment. Neither significant abnormality was elicited from the general physical examination on admission nor was any focal neurologic deficit detected on neurologic examination.

CT scan demonstrated a $5 \times 4 \times 3 \mathrm{~cm}$ mass located in the right frontobasal region adjacent to the anterior falx, accompanied with minimal perifocal edema (Fig. 1a). The mass was heterogeneously intensed with a large amount of calcification around the rim. T2-weighted magnetic resonance images revealed a heterogeneously hyperintensed 


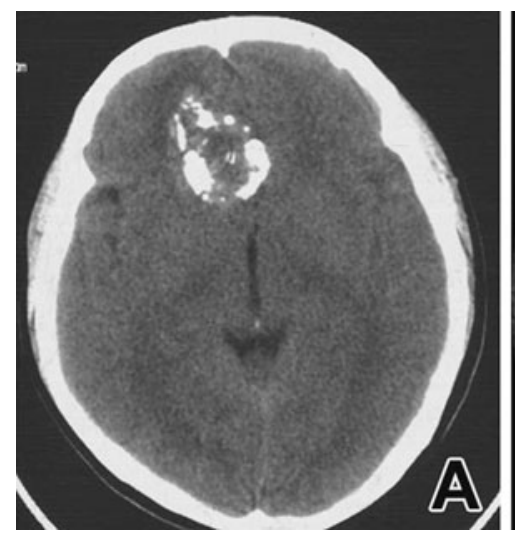

Fig. 1 a CT scan shows a large mass located in the right frontobasal region adjacent to the anterior falx. The mass is heterogeneously intense, with a large amount of calcification. b Axial T2-weighted
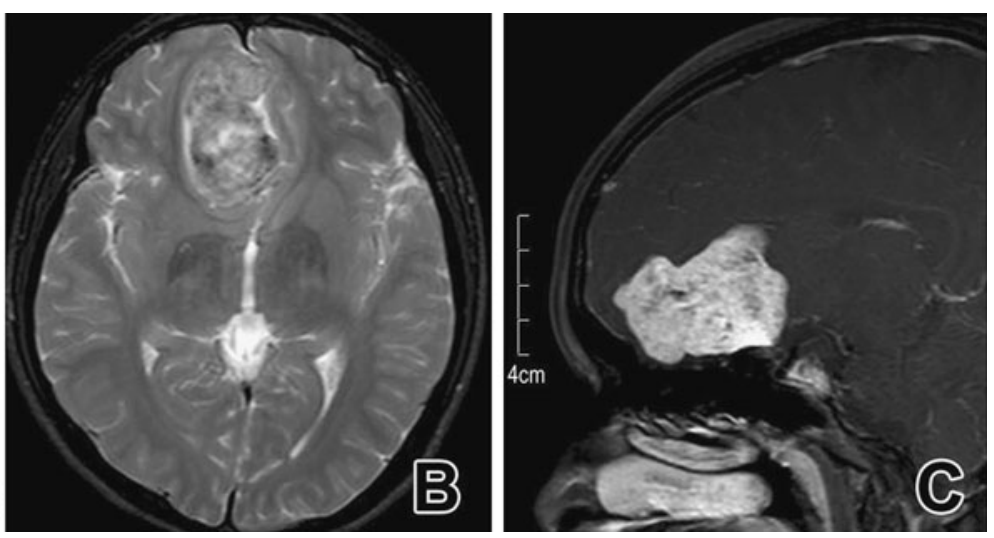

MRI shows a huge subfrontal heterogeneously hyperintense mass. c Sagittal T1-weighted MRI with gadolinium shows strong contrast enhancement of the lesion
Fig. 2 a Photomicrography shows the characteristic features of schwannoma composed of benign spindle-shaped cells, with elongated nuclei and fibrillary cytoplasm (Antoni A pattern), and less cellular, loosely textured tumor areas (Antoni B) (H\&E 200×). b Immunohistochemistry shows that the tumor cells are positive for $\mathrm{S}-100$ protein $(400 \times)$
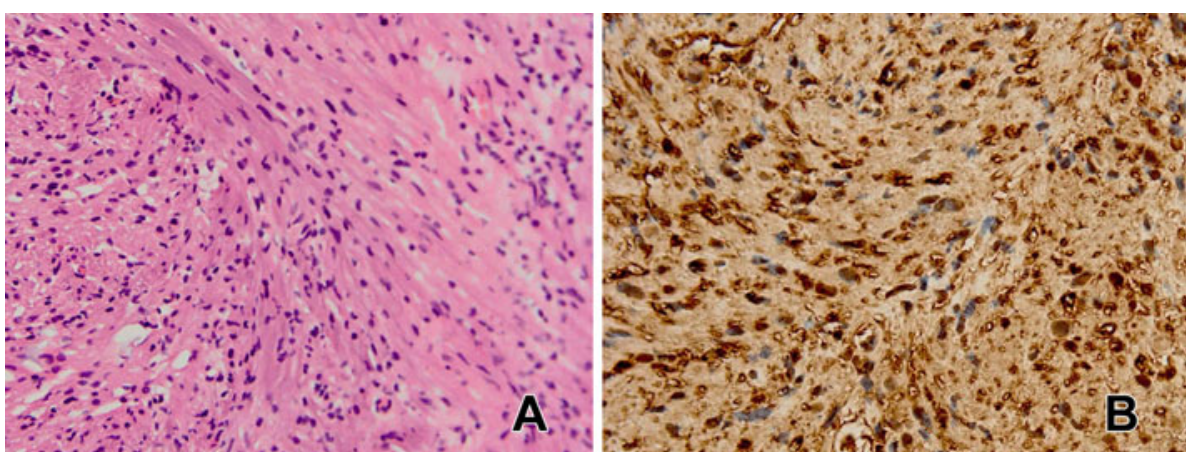

mass in the right frontal region near the midline, causing elevation of the right frontal lobe. The mass was heterogeneously enhanced after IV administration of gadolinium (Fig. 1b, c). No evidence of dural tail or extension into the ethmoid sinus was seen.

\section{Surgical procedures}

Right frontal craniotomy was performed. A 5-cm extra axial tumor was found at the base of the anterior cranial fossa and totally resected. The tumor was solid, moderately vascular and firmly adhered to the right olfactory groove with abundant calcification. The right olfactory tract was not identifiable. After total resection of the tumor, the cribriform plate of ethmoid bone was seen erosive. The gross appearance of the tumor looked like an olfactory groove meningioma.

\section{Histopathology}

Histologic examination revealed that the resected tissue was composed of spindle-shaped cells, with elongated nuclei and fibrillary cytoplasm (Antoni A pattern), and less cellular and loosely textured tumor areas (Antoni B). Immunohistochemistry showed that the tumor cells were positive for S-100 protein, confirming the diagnosis of schwannoma (Fig. 2).

The postoperative course was uneventful. Postoperative imaging confirmed gross-total resection of the tumor (Fig. 3). The patient was discharged 7 days after surgery without new neurologic deficits, and follow-up visits demonstrated normal neurologic function.

\section{Literature review and analysis}

The PubMed database was searched online (Pubmed, http://pubmed.com/) in the English language. Search query using the terms olfactory schwannoma and subfrontal schwannoma in titles and/or abstracts revealed additional 34 cases (Table 1). It was found that the age and sex distributions of the 35 patients including ours with subfrontal schwannomas were different from those of patients with ordinary intracranial schwannomas. The mean age of the 35 patients was $32.7 \pm 14.0$ years, which was younger than that of patients with schwannoma in other common 

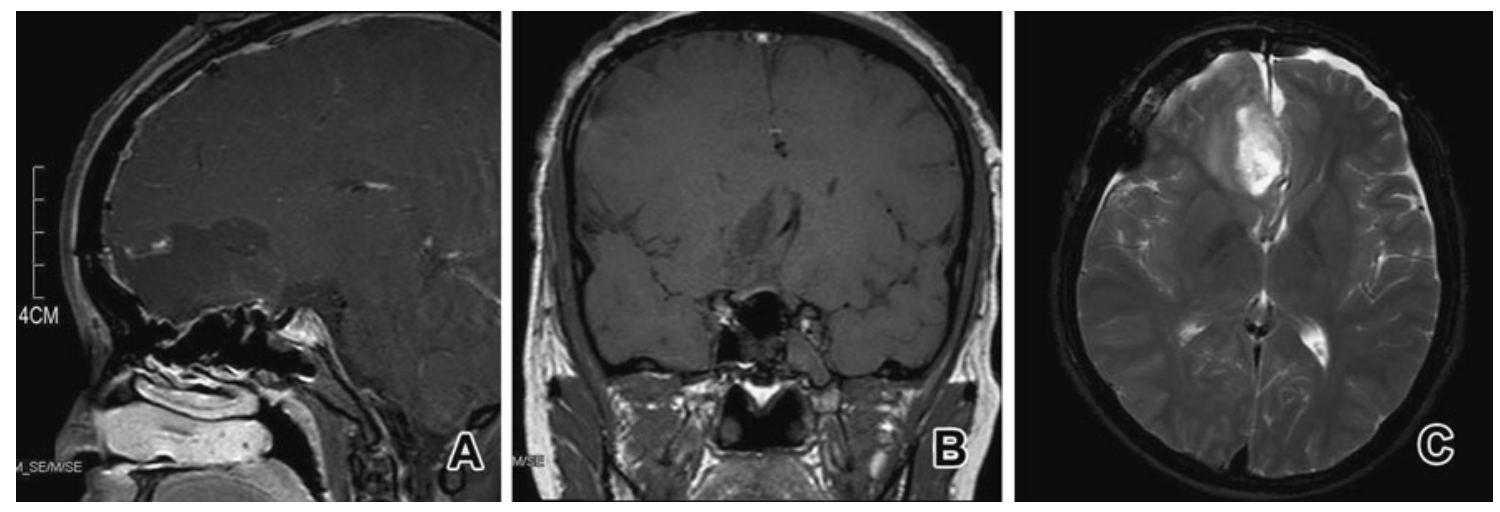

Fig. 3 Postoperative sagittal and coronal enhanced T1WI MRI and T2WI MRI shows complete removal of the tumor

sites. In addition, there were more males $(57.1 \%)$ than females, the male/female ratio being 1.14:1 versus $1: 1.5-2$ for ordinary intracranial schwannomas.

\section{Discussion}

Schwannomas are benign tumors derived from Schwann cells. Theoretically, the olfactory nerve, as part of the central nervous system, does not contain any Schwann cells and cannot develop schwannomas. Thus, the origin of olfactory schwannomas is enigmatic. Various developmental and non-developmental hypotheses [1] have emerged in an attempt to explain the possible origin of olfactory schwannomas. The developmental theories include transformation of mesenchymal pial cells into ectodermal Schwann cells [2], and migration or displacement of neural crest within the substance of the central nervous system [3-5]. On the other hand, the non-developmental theories argue that olfactory schwannomas arise from Schwann cells normally present on adjacent structures such as anterior ethmoidal nerves innervating the anterior cranial fossa and the olfactory groove, the meningeal branch of the trigeminal nerve [6], the filia olfactoria which develop a Schwann cell layer about $0.5 \mathrm{~mm}$ beyond the olfactory bulbs, adrenergic nerve fibers innervating cerebral arterioles [7], a kind of 'ensheathing cell' of the olfactory nerve that expresses phenotypic features of both astrocyte and Schwann cell [2], and terminal nerve (cranial nerve 0) [8]. In addition, post-trauma reactive changes including formation of schwann cells from multipotential mesenchymal cells in patients with pathological changes like multiple sclerosis or infarction have also been described $[9,10]$.

Olfactory groove meningioma should be highly suspected in differential diagnosis of an extra-axial anterior cranial fossa mass involving the cribriform plate. However, subfrontal schwannoma can have similar neuroradiological features to olfactory groove meningioma, including extraaxial location, calcification, contrast enhancement and perifocal edema, thus making pre-operative differentiation of the two conditions difficult. Clinically, young age at presentation, the presence of bone scalloping on CT, the absence of dural tail sign and low vascularity may help us to make differential diagnosis between schwannoma and meningioma before surgery. In addition, bone erosion in olfactory schwannomas is usually destructive (17 of 35), while meningioma tends to induce hyperostosis (Table 1). Esthesioneuroblastoma and carcinoma of the paranasal sinus tend to be more aggressive, though they should be excluded from the differential diagnosis. Immunohistochemically, schwannomas always showed strong positive for S-100 and negative for EMA.

Olfactory groove schwannomas are classified into two main types by Adachi et al. [1]: schwannomas arising from the olfactory site such as the olfactory groove or cribriform plate, and those arising from non-olfactory sites. Accordingly, our case should belong to the first type as evidenced by the intraoperative findings. Recently, some researchers doubted whether these olfactory groove schwannomas are truly schwannomas. Yasuda et al. [11] individualized the first case of olfactory ensheathing cell tumor (OECT) based on immunohistochemical findings and suspected OECs as one of the origins of olfactory schwannoma. Embryologically, OECs derive from olfactory placodes, whereas Schwann cells originate from the neural crests. Despite the different origin of their cells, olfactory groove schwannoma and OECT have similar clinical, imaging, and histologic features, and can only be distinguished by immunohistochemical staining.

\section{Conclusion}

Olfactory groove schwannomas are extremely rare tumors, occurring less frequently than any other intracranial nerve 


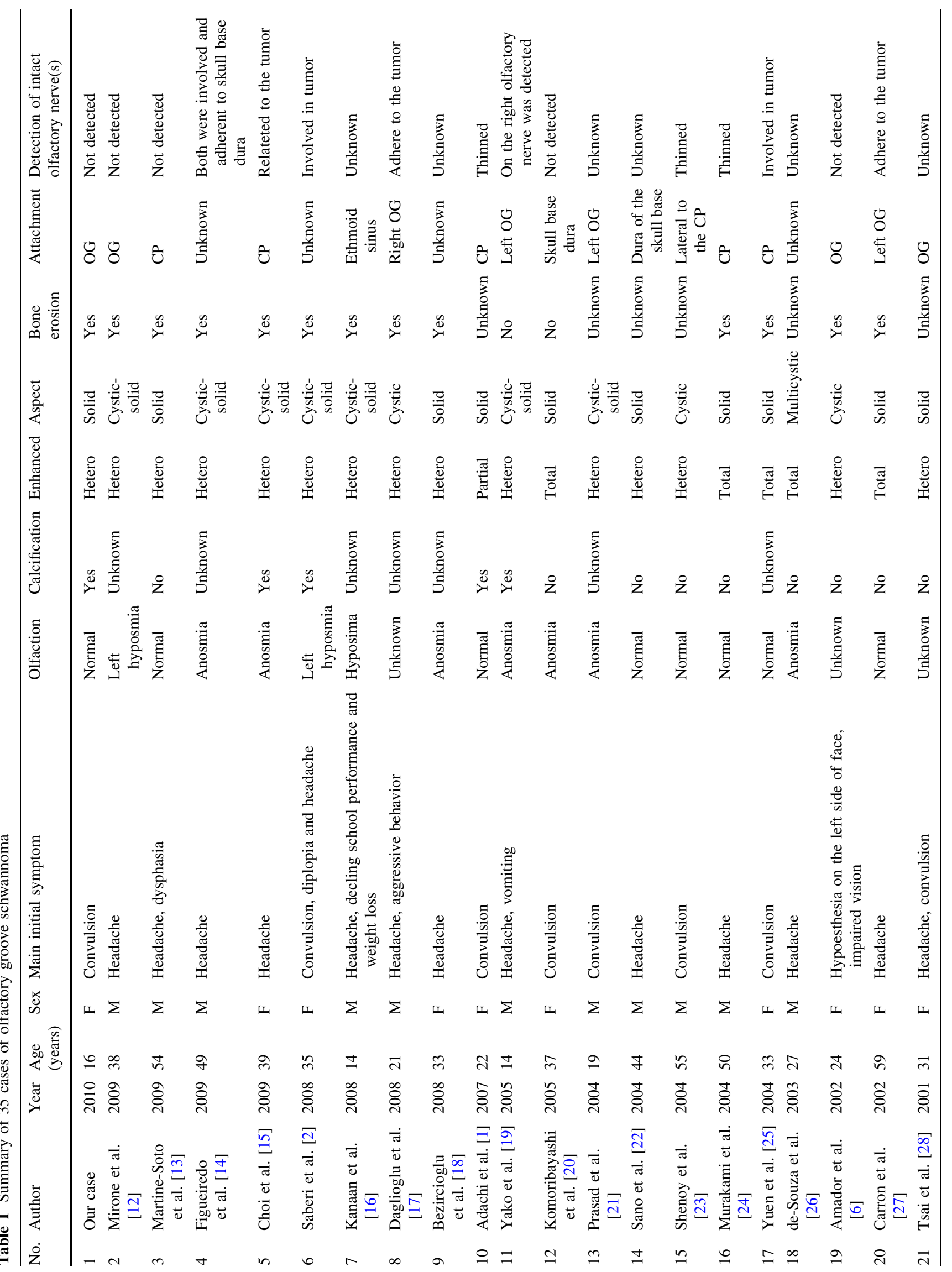




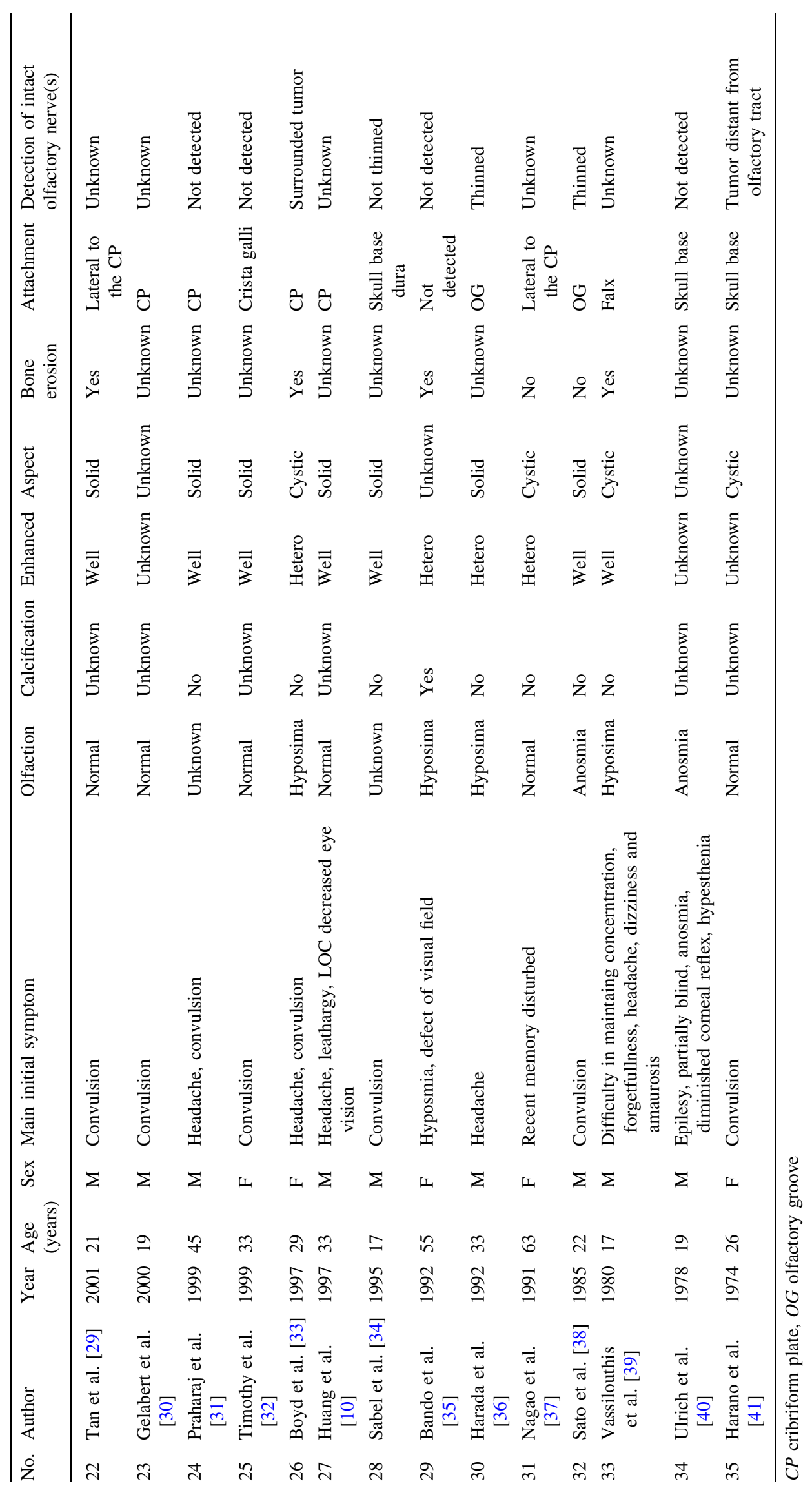


schwannoma. Complete removal is curative, but subtotal resection may be an acceptable option for the slow-growing nature of these tumors. Schwannoma should be kept in mind in differential diagnosis of anterior cranial fossa neoplasms, especially in young males. Further research on the pathogenesis and the origin of olfactory groove schwannoma is needed.

Open Access This article is distributed under the terms of the Creative Commons Attribution Noncommercial License which permits any noncommercial use, distribution, and reproduction in any medium, provided the original author(s) and source are credited.

\section{References}

1. Adachi K, Yoshida K, Miwa T et al (2007) Olfactory schwannoma. Acta Neurochir (Wien) 149(6):605-610 (discussion 610-611)

2. Saberi H, Khashayar P (2008) Olfactory groove schwannoma masquerading as an orbital mass. Neurosciences (Riyadh) 13(1): 73-76

3. Frim DM, Ogilvy CS, Vonsttal JP et al (1992) Is intracerebral schwannoma a developmental tumor of children and young adults? Pediatr Neurosurg 18:190-194

4. Ramamurthy B, Anguli VC, Iyer CGS (1958) A case of intramedullary neurinoma. J Neurosurg Psychiatry 27:92-94

5. Redekop G, Elisevich K, Gilbert J (1990) Fourth ventricular schwannoma. Case report. J Neurosurg 73:777-781

6. Amador AR, Santonja C, Del Pozo JM et al (2002) Olfactory schwannoma. Eur Radiol 12(4):742-744

7. Sturm KW, Bohnis G, Kosmaoglu V (1968) Uber ein Neurinom der Lamina cribrosa. Zbl Neurochir 29:217-222

8. Gibson AAM, Hendrick EB, Connen PE (1966) Intracerebral schwannoma-a report of a case. J Neurosurg 24:552-557

9. Auer KN, Budny J, Drake CG et al (1982) Frontal lobe perivascular schwannoma. J Neurosurg 56:154-157

10. Huang PP, Zagzag D, Benjamin V (1997) Intracranial schwannoma presenting as a subfrontal tumor: case report. Neurosurgery 40(1):194-197

11. Yasuda M, Higuchi O, Takano S et al (2006) Olfactory ensheathing cell tumor: a case report. J Neurooncol 76:111-113

12. Mirone G, Natale M, Scuotto A et al (2009) Solitary olfactory groove schwannoma. J Clin Neurosci 16(3):454-456

13. Martinez-Soto L, Alfaro-Baca R, Torrecilla-Sardon $\mathrm{M}$ et al (2009) A new case of "olfactory schwannoma"; presentation and literature review. Neurocirugia (Astur) 20(3):294-297

14. Figueiredo EG, Gomes MQ, Soga Y et al (2009) A rare case of olfactory groove schwannoma. Arq Neuropsiquiatr 67(2B): 534-535

15. Choi YS, Sung KS, Song YJ et al (2009) Olfactory schwannoma-case report. J Korean Neurosurg Soc 45(2):103-106

16. Kanaan HA, Gardner PA, Yeaney G et al (2008) Expanded endoscopic endonasal resection of an olfactory schwannoma. J Neurosurg Pediatr 2(4):261-265

17. Daglioglu E, Okay O, Dalgic A et al (2008) Cystic olfactory schwannoma of the anterior cranial base. $\mathrm{Br} \mathrm{J}$ Neurosurg 22(5):697-699
18. Bezircioglu H, Sucu HK, Rezanko T et al (2008) Nasal-subfrontal giant schwannoma. Turk Neurosurg 18(4):412-414

19. Yako K, Morita A, Ueki K et al (2005) Subfrontal schwannoma. Acta Neurochir (Wien) 147(6):655-657 (discussion 657-658)

20. Komoribayashi N, Arai H, Kojo T et al (2005) Subfrontal schwannoma: case report. No Shinkei Geka 33(6):601-605

21. Prasad D, Jalali R, Shet $T$ (2004) Intracranial subfrontal schwannoma treated with surgery and 3D conformal radiotherapy. Neurol India 52(2):248-250

22. Sano H, Hayashi Y, Hasegawa M et al (2004) Subfrontal schwannoma without hyposmia-case report. Neurol Med Chir (Tokyo) 44(11):591-594

23. Shenoy SN, Raja A (2004) Cystic olfactory groove schwannoma. Neurol India 52(2):261-262

24. Murakami M, Tsukahara T, Hatano T (2004) Olfactory groove schwannoma-case report. Neurol Med Chir Tokyo 44(4): 191-194

25. Yuen A, Trost N, McKelvie P et al (2004) Subfrontal schwannoma: a case report and literature review. J Clin Neurosci 11(6): 663-665

26. de Souza HL, Ramos AM, Ramos CC et al (2003) Olfactory groove schwannoma: case report. Arq Neuropsiquiatr 61(1): $125-128$

27. Carron JD, Singh RV, Karakla DW et al (2002) Solitary schwannoma of the olfactory groove: case report and review of the literature. Skull Base 12(3):163-166

28. Tsai YD, Lui CC, Eng HL et al (2001) Intracranial subfrontal schwannoma. Acta Neurochir (Wien) 143(3):313-314

29. Tan TC, Ho LC, Chiu HM et al (2001) Subfrontal schwannoma masquerading as meningioma. Singapore Med J 42(6):275-277

30. Gelabert M, Fernandez J, Lopez E (2000) Schwannoma of the olfactory groove. Neurologia 15(9):404-405

31. Praharaj SS, Vajramani GV, Santosh V et al (1999) Solitary olfactory groove schwannoma: case report with review of the literature. Clin Neurol Neurosurg 101(1):26-28

32. Timothy J, Chakrabarty A, Rice A et al (1999) Olfactory groove schwannoma revisited. Acta Neurochir (Wien) 141(6):671-672

33. Boyd JH, Dalsaso TA Jr, Bee CS et al (1997) Subfrontal schwannoma with intracranial mucocele: a case report. Am J Otolaryngol 18(1):72-75

34. Sabel LH, Teepen JL (1995) The enigmatic origin of olfactory schwannoma. Clin Neurol Neurosurg 97(2):187-191

35. Bando K, Obayashi M, Tsuneharu F (1992) A case of subfrontal schwannoma. No Shinkei Geka 20(11):1189-1194

36. Harada T, Kawauchi M, Watanabe M et al (1992) Subfrontal schwannoma-case report. Neurol Med Chir (Tokyo) 32(13): 957-960

37. Nagao S, Aoki T, Kondo S et al (1991) Subfrontal schwannoma: a case report. No Shinkei Geka 19(1):47-51

38. Sato S, Toya S, Nakamura T et al (1985) Subfrontal schwannoma: report of a case. No Shinkei Geka 13(8):883-887

39. Vassilouthis J, Richardson AE (1980) Subfrontal schwannoma. Report of a case. Acta Neurochir (Wien) 53(3-4):259-266

40. Ulrich J, Levy A, Pfister C (1978) Schwannoma of the olfactory groove. Case report and review of previous cases. Acta Neurochir (Wien) 40(3-4):315-321

41. Harano H, Hori S, Kamata K et al (1974) A case report of subfrontal schwannoma (author's transl). No Shinkei Geka 2(9): 643-647 